\title{
Vipulanandan $p-q$ model to predict the effect of pressurised water on the strengths of gypsum rock in Kurdistan Region, Iraq
}

Ahmed Mohammed

Department of Civil Engineering, College of Engineering,

University of Sulaimani, Sulaymaniyah, Iraq, Kurdistan Region (corresponding

author: Ahmedsalih_m@yahoo.com, ahmed.mohammed@univsul.edu.iq)
Nihad Salih

Department of Irrigation Engineering, College of Engineering, University of Sulaimani, Sulaymaniyah, Iraq, Kurdistan Region

In this study, the effects of soaking time and confining water pressure on the compressive and flexural strengths of rock due to the dissolution of gypsum content in rock samples with $96 \%$ gypsum $\left(\mathrm{CaSO}_{4} \cdot 2 \mathrm{H}_{2} \mathrm{O}\right)$ content collected from northern Iraq (Kurdistan Region) were investigated. Experiments on compressive strength and flexural strength were performed on gypsum rock samples in normal and pre-saturated conditions. The pre-saturated samples were submerged in distilled water for 35, 70 and $105 \mathrm{~d}$ and subjected to confined pressures of $0-0.5 \mathrm{MPa}$. Thermogravimetric analyses showed a notable reduction in the weight of gypsum rock between 25 and $120^{\circ} \mathrm{C}$. Also, the total weight loss at $800^{\circ} \mathrm{C}$ for the field rock sample was $7.53 \%$. The weight loss of the gypsum rock increased with increasing soaking time and confining water pressure. The gypsum content decreased by $11 \%$ under a soaking time of $105 \mathrm{~d}$ and a confining water pressure of $0.5 \mathrm{MPa}$ with respect to the natural samples. The compressive strength of the normal gypsum rock was $19.6 \mathrm{MPa}$, and it decreased by 68 and $90 \%$ after $105 \mathrm{~d}$ of soaking under confining water pressures of 0 and $0.5 \mathrm{MPa}$, respectively. The flexural strength of the normal gypsum rock was $10.8 \mathrm{MPa}$, and it decreased by 65 and $91 \%$ after $105 \mathrm{~d}$ of soaking under confining water pressures of 0 and $0.5 \mathrm{MPa}$, respectively. Two non-linear constitutive models were used to simulate the experimental stress-strain relationships in various conditions. The constitutive model parameters were sensitive to the gypsum content. Based on the methods of the coefficients of determination $\left(R^{2}\right)$ and root mean square errors, the non-linear constitutive model (Vipulanandan $p-q$ model) predicted the stress-strain behaviour for the gypsum rock very well.

\section{Notation}

$a, b, c \quad$ linear model parameters

$b \quad$ width of the tested beam

$d \quad$ depth of the tested beam

$E_{\mathrm{i}} \quad$ initial modulus of elasticity

$k \quad$ initial model parameter for gypsum rock

$L$ and $D \quad$ length and thickness of a sample, respectively

$N \quad$ number of experimental data points

$P \quad$ confining water pressure

$P_{\max } \quad$ load at a given point (maximum)

$p$ and $q \quad$ material parameters

$R^{2} \quad$ coefficient of determination

$t \quad$ soaking time

$\bar{x} \quad$ mean of calculated data

$x_{i} \quad$ calculated data from the model

$\bar{y} \quad$ mean of the actual test data

$y_{i} \quad$ actual test data

$\varepsilon \quad$ axial strain: \%

$\sigma \quad$ compressive stress

$\sigma_{\mathrm{c}} \quad$ compressive strength

$\sigma_{\mathrm{f}} \quad$ flexural strength

$\sigma_{\text {fo }} \quad$ initial flexural strength

\section{Introduction}

Gypsum $\left(\mathrm{CaSO}_{4} \cdot 2 \mathrm{H}_{2} \mathrm{O}\right)$ rocks cover more than $20 \%$ of the earth's surface, with 7 million $\mathrm{km}^{2}$ covered by highly soluble gypsum- bearing rocks (Dreybrodt et al., 2002). Construction failures and geological problems have globally resulted from the presented properties of gypsum content (GC), two examples being the surface collapse of roads and bridge in Ripon, UK (Cooper and Saunders, 2002) and the $400 \mathrm{~m}^{3}$ sinkhole and $5.5 \mathrm{~m}$ land surface drop in the north-eastern side of Mosul in Iraq (Al-Layla and Thabet, 1990). Gypsum is a soluble mineral deposit resulting from evaporation of natural water. It can transform to anhydrite by losing its hydration water, or anhydrite can transform to gypsum by the addition of water (Ingebritsen and Sanford 1999; Jaworska, 2010). The conversion of anhydrite to gypsum may cause over $60 \%$ increase in the volume of the solid phase, which causes lots of engineering problems (Salih et al., 2015). The average uniaxial compressive strength of gypsum rock has been found to be in the range 9-16 MPa (HaiFei et al., 2009; Liang et al., 2012; Shafiei et al., 2008) as shown in Figure 1. The influence of saturation on the compressive properties of gypsum rock has been considered by several research studies; usually with increasing soaking time (i.e. increasing degree of saturation), the strength of gypsum rock decreases (Heidari et al., 2012; Salih et al., 2015; Vásárhelyi and Ván, 2006). Water is suggested to be a significant factor influencing the stability and mechanical properties of gypsum rock (Dusseault, 2011; Mohammed and Mahmood, 2018a, 2018b; Salih et al., 2015). Among the various notable problems investigated by various research studies, gypsum rock can experience formation of karst features (caves 


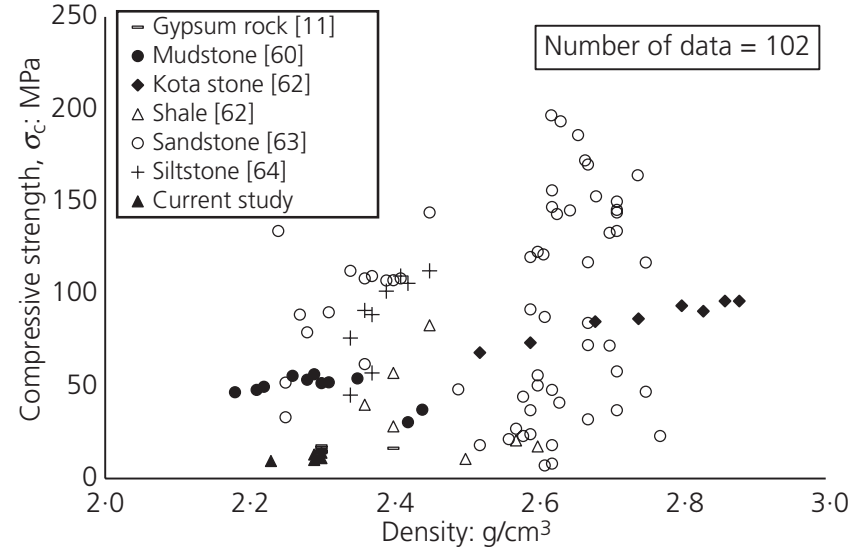

Figure 1. Variation in compressive strength with density for rocks

and sinkholes), due to continuous dissolution (Johnson, 2005; Shafiei et al., 2008; Y1lmaz, 2001). The dissolution of gypsum is dependent on the surface area exposed to water. The solubility of gypsum is greater in distilled water than in water containing more calcium $\left(\mathrm{Ca}^{2+}\right)$ and sulfate $\left(\mathrm{SO}_{4}{ }^{2-}\right)$ ions (Fengxiang et al., 1983). In water saturated with calcium sulfate $\left(\mathrm{CaSO}_{4}\right)$, gypsum solubility was found to be about $1 \cdot 83-2 \cdot 5 \mathrm{~g} / 1$ at $20^{\circ} \mathrm{C}$, the average of which $(2 \cdot 2 \mathrm{~g} / \mathrm{l})$ is approximately $1 / 160$ of the solubility of ordinary salt $(360 \mathrm{~g} / \mathrm{l})$ and 1.5 times the solubility of calcium carbonate $\left(\mathrm{CaCO}_{3}\right)(1.5 \mathrm{mg} / \mathrm{l})$ (Bell, 1994; Gumusoglu and Ulker, 1982; Y1lmaz, 2001). Gypsum is susceptible to rapid dissolution whenever there is an active movement of groundwater, which is unsaturated with calcium sulfate (Salih et al., 2015). Gypsum, like calcium carbonate and salt, dissolves reversibly, but anhydrite does not. When anhydrite is dissolved, it forms a solution of calcium sulfate which, at common temperatures and pressures, is in equilibrium with the solid phase of gypsum, but not with anhydrite. If disequilibrium of the solid-solvent system occurs, gypsum precipitates. This is due to the instability of anhydrite under normal surface and shallow subsurface thermobaric conditions (Klimchouk, 1996).

Leaching of gypsum is an essential point for the dissolution process, which has been also studied. Unbonded gypsum leaches out quickly due to the water percolating through the fissures at the boundary between gypsum and the surrounding rock. Rock collapse in the roofs of tunnels and mines often occurs in bending conditions (Fengxiang et al., 1983). Elizzi (1976) and Ali (1979) studied the difference between compression and tension strain in four-point mode bending tests for gypsum rock. The studies showed that the compressive strain from the four-point bending test for a gypsum rock sample was greater than the tension strain. Efimov (2009) highlighted the method of bending testing. The result showed that the three-point bending test for gypsum rock showed higher tension compared with the four-point bending test. Based on the information from various research studies performed on different types of rock, the size $(L / D$, where $L$ and $D$ are the length and thickness of the sample, respectively) for the compression test varied from $0 \cdot 5$ to 3 . The different beam sizes $(L \times W \times D)$ used for flexural strength tests found in the literature are summarised in Table 1.

In this study, non-linear models were used to predict the longterm stress-strain behaviour of gypsum rock subjected to different confining water pressures. The effect of the confining water pressure on the dissolution of the GC was also studied. At least three samples were tested for each condition.

\section{Vipulanandan $p-q$ model}

The stress-strain behaviours of strain-softening materials such as concrete, glass-fibre-reinforced polymer concrete, fine sand grouted with sodium silicate, sulfate contaminated clay soil and cement mortar were predicted using the Vipulanandan $p-q$ model (Mebarkia and Vipulanandan, 1992; Mohammed and Vipulanandan, 2014; Vipulanandan and Paul, 1990). Vipulanandan and Usluogullari (2011) modelled the stress-strain behaviour of Portland cement-stabilised sand using the $p-q$ model. Vipulanandan and Mohammed (2015a) used the Vipulanandan $p-q$ model for predicting the piezoresistive behaviour of smart cement modified with iron oxide nanoparticles. Also, the Vipulanandan $p-q$ model was used to predict the electrical resistivity against curing time of smart oil well cement (Mohammed and Vipulanandan, 2015; Vipulanandan and Mohammed, 2015b).

\section{Aims and objectives}

The overall objective of this study was to investigate the effect of long-term soaking time and confining water pressure on the compressive and flexural strengths of gypsum rock. The specific objectives are as follows

n investigation of the effect of the soaking time and confined water pressure on the dissolution of GC

- the long-term compressive strength and flexural strength behaviour of normal gypsum rock samples and pre-saturated samples subjected to different confining water pressures

- quantification of the long-term stress-strain relationship of gypsum rock under different confining water pressures

- correlation between the compressive strength and flexural strength of gypsum rock.

\section{Materials and methods}

\section{X-ray diffraction characterisation}

$\mathrm{X}$-ray diffraction (XRD) was used to characterise the chemical composition of gypsum rock. Specimens for XRD were prepared from an air-dried gypsum rock sample. The sample $(\approx 2 \mathrm{~g})$ was placed in an acrylic sample holder which was about $3 \mathrm{~mm}$ deep. The sample was analysed by using parallel-beam optics with copper $(\mathrm{Cu}) \mathrm{K} \alpha$ radiation at $40 \mathrm{kV}$ and $30 \mathrm{~mA}$. The sample was scanned for reflections $(2 \theta)$ in the range $0-80^{\circ}$ at a step size of $0.02^{\circ}$ and a $2 \mathrm{~s}$ count time per step (Vipulanandan and Mohammed, 2015b). 
Table 1. Literature review of the dimensions of samples for compression and flexural strength tests

\begin{tabular}{|c|c|c|c|c|c|c|}
\hline \multicolumn{4}{|c|}{ Compression test } & \multicolumn{3}{|c|}{ Flexural test } \\
\hline Reference & Type of rock & Size of sample & $\begin{array}{l}\text { Length/ } \\
\text { diameter } \\
(L / D)\end{array}$ & Reference & Type of rock & $\begin{array}{c}L \times W \times D: \\
\mathrm{mm}\end{array}$ \\
\hline Lundborg (1967) & Granite & $20,30,40$ and $60 \mathrm{~mm}$ dia. & 1 & $\begin{array}{l}\text { Xeidakis } \\
\text { et al. } \\
\text { (1996) }\end{array}$ & $\begin{array}{l}\text { Marble, } \\
\text { calcite and } \\
\text { dolomitic }\end{array}$ & $180 \times 40 \times 20$ \\
\hline $\begin{array}{l}\text { Bieniawski et al. (1967), Singh and Singh } \\
\text { (1993), Y.lmaz and Sendir (2002), } \\
\text { Brady and Brown (2013) }\end{array}$ & Gypsum rock & NX (52 mm dia.) & 2 & $\begin{array}{l}\text { Biolzi et al. } \\
(2001)\end{array}$ & Granite & $240 \times 40 \times 30$ \\
\hline Ali (1979) & Gypsum rock & $\begin{array}{l}38.1 \mathrm{~mm} \text { dia. } \times 114.3 \mathrm{~mm} \\
\text { high and } 50.8 \mathrm{~mm} \text { dia. } \times \\
152.4 \mathrm{~mm} \text { high }\end{array}$ & 3 & $\begin{array}{l}\text { Coviello } \\
\text { et al. } \\
\text { (2005) }\end{array}$ & Calcarenite & $130 \times 50 \times 40$ \\
\hline Whittles et al. (2006) & Sandstone & $25 \mathrm{~mm}$ dia. $\times 50 \mathrm{~mm}$ high & 2 & $\begin{array}{l}\text { Biolzi et al. } \\
(2011)\end{array}$ & Sandstone & $180 \times 40 \times 40$ \\
\hline Agustawijaya (2007) & $\begin{array}{l}\text { Sandstone } \\
\text { and } \\
\text { siltstone }\end{array}$ & 54 mm dia. & $1 \cdot 6-2 \cdot 5$ & $\begin{array}{l}\text { Aliha et al. } \\
\text { (2009) }\end{array}$ & Granite & $220 \times 40 \times 20$ \\
\hline Özkan et al. (2009) & Rock salt & $\begin{array}{l}25,50,75,100 \text { and } \\
125 \mathrm{~mm} \text { dia. }\end{array}$ & $0 \cdot 5-2 \cdot 5$ & $\begin{array}{c}\text { Moonen } \\
(2009)\end{array}$ & Sandstone & $240 \times 48 \times 24$ \\
\hline Cho et al. (2010) & $\begin{array}{l}\text { Sulfaset } \\
\text { synthetic } \\
\text { rock }\end{array}$ & $55 \mathrm{~mm}$ dia. $\times 110 \mathrm{~mm}$ high & 2 & $\begin{array}{l}\text { Efimov } \\
(2009)\end{array}$ & Granite & $120 \times 20 \times 20$ \\
\hline Liang et al. (2012) & Salt rock & $50 \mathrm{~mm}$ dia. $\times 100 \mathrm{~mm}$ high & 2 & $\begin{array}{l}\text { Chen and } \\
\text { Azzam } \\
\text { (2007) }\end{array}$ & Sandstone & $250 \times 50 \times 50$ \\
\hline Current study & Gypsum rock & 54 mm dia. & $2 \cdot 5$ & $\begin{array}{l}\text { Current } \\
\text { study }\end{array}$ & Gypsum rock & $140 \times 40 \times 20$ \\
\hline Remarks & $\begin{array}{l}\text { Different } \\
\text { types of } \\
\text { rock were } \\
\text { used }\end{array}$ & $\begin{array}{l}\text { Diameters varied from } 20 \\
\text { to } 55 \mathrm{~mm}\end{array}$ & $\begin{array}{l}\text { L/D varied } \\
\text { from } 0.5 \\
\text { to } 3\end{array}$ & Remarks & $\begin{array}{l}\text { Different } \\
\text { types of } \\
\text { rock were } \\
\text { used }\end{array}$ & $\begin{array}{l}\text { Different } \\
L \times W \times D \\
\text { values were } \\
\text { used }\end{array}$ \\
\hline
\end{tabular}

\section{Thermogravimetric analysis}

Thermogravimetric analysis (TGA) curves, \% weight loss with temperature (TGA) and its derivative (\% weight change $/{ }^{\circ} \mathrm{C}-$ derivative thermogravimetry (DTG)), were recorded using Setaram TGA 500 apparatus at a heating rate of $10^{\circ} \mathrm{C} / \mathrm{min}$ for a sample of about $20 \mathrm{mg}$ (Khalil and Gad, 1972). TGA and DTG curves for the field gypsum rock were obtained. The test sample was loaded in a platinum pan (three-quarters full). This was followed by introduction of nitrogen $\left(\mathrm{N}_{2}\right)$ gas into the TGA compartment for $5 \mathrm{~min}$ to purge the likely oxygen in the environment of the system. After purging, the sample was heated in the nitrogen atmosphere from room temperature to the maximum of $800^{\circ} \mathrm{C}$ (Vipulanandan and Mohammed, 2015b).

\section{Compression test (ASTM D 7012-10)}

In this study, an area in northern Iraq (Kurdistan Region) in Sulaymaniyah City (elevation $=966 \mathrm{~m}, 0495932$ 38S and 3945243 UTM) that is rich with massive layers of gypsum rock was selected. Sufficient block samples for all the laboratory tests were collected. The site features a massive gypsum rock layer. The gypsum rock locally contains marl or clay impurities within cracks. Gypsum rock samples were collected from the mined layer of gypsum. Based on the information from the literature (Table 1), the collected samples were cored in NX size ( $54 \mathrm{~mm}$ dia.) and $L / D$ was selected to be $2 \cdot 5$
(ASTM D 7012-10 (ASTM, 2010a)). The field rock samples were washed to remove the fine materials and were kept in an oven at $25^{\circ} \mathrm{C}$ for $48 \mathrm{~h}$ in order to obtain constant weight. Oven-dried $\left(25^{\circ} \mathrm{C}\right)$ compression and flexural samples were kept inside a vacuum desiccator to be evacuated for $3 \mathrm{~h}$. The sample preparation and testing procedures are explained in Figure 2.

\section{Pressure vessels}

Steel pressure vessels were used to allow the simulation of water pressures. The pressure vessels are cylindrical containers; the base and side-walls were made of stainless steel, while the top was made from a specific plastic material suitable for vessel conditions as shown in Figure 3. One inlet valve located on the top surface was used to introduce air to pressurise the vessel. An outlet valve was used to extract the water from the vessel. Samples could be placed into and removed from the vessel through the removable gate located at the top centre of the vessel. Plastic pipes, special connections and a pressure meter were prepared to be used with the vessels as shown in Figure 3. All the tests were performed at the room temperature of $24 \pm 1{ }^{\circ} \mathrm{C}$.

\section{Saturation process}

A specific procedure for saturating the normal gypsum rock samples was considered (Hawkes and Mellor, 1970). Distilled 


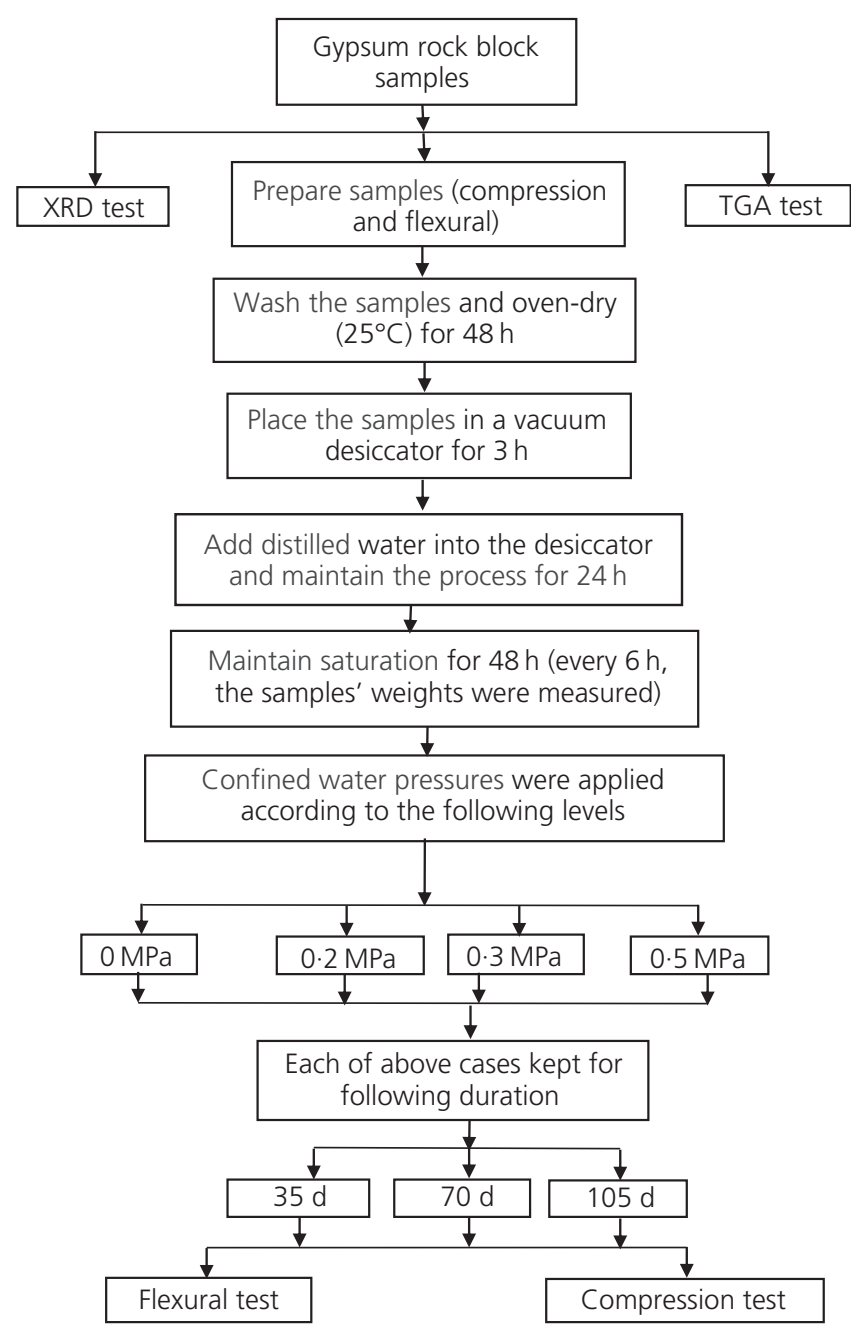

Figure 2. Flow diagram of laboratory testing

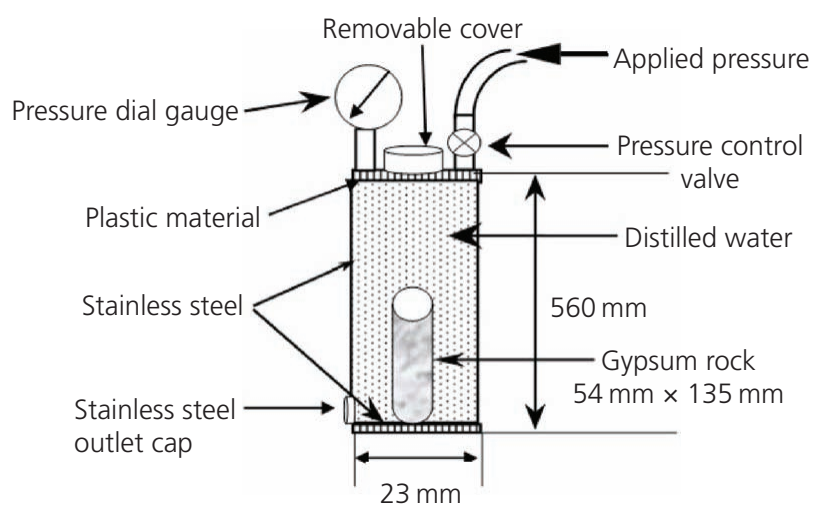

Figure 3. Schematic representation of the gypsum rock saturation system

water was added into the desiccator, and the evacuation process was continued for $24 \mathrm{~h}$ (Ali, 1979; Rauh et al., 2006). The weight of the samples was measured in real time every $6 \mathrm{~h}$ using a
$0 \cdot 001 \mathrm{~g}$ electronic balance to check if a constant weight for the samples was obtained. After $12 \mathrm{~h}$, the samples' weight was constant. The first step involved saturating the gypsum rock samples under atmospheric pressure in containers with a known volume of water. The samples were soaked inside the containers for durations of 35,70 and $105 \mathrm{~d}$; the change in the samples' weight and the electrical conductivity (EC) of the water-dissolved gypsum were recorded at $7 \mathrm{~d}$ intervals. Three samples with the same size, colour and origin were considered for each time interval. Then, the second step was conducted by using pressure vessels to saturate the samples and applying three different levels of confining water pressures of $0 \cdot 2,0.35$ and $0.5 \mathrm{MPa}$ to the presaturated samples.

A confining water pressure of $0.5 \mathrm{MPa}$ is equivalent to a $50 \mathrm{~m}$ high water column above the sample, simulating the conditions in the reservoir of hydraulic structure projects, which directly affects the gypsum-rich substrates near the surface under the foundation. The flow diagram of the laboratory programme is shown in Figure 2.

\section{Compressive strength test (ASTM D 7012-10)}

Cylindrical specimens $54 \mathrm{~mm}$ in diameter and $135 \mathrm{~mm}$ high $(2.13$ inches dia. $\times 5.30$ inches high) were tested at a predetermined controlled loading rate. Compression tests were performed on the normal gypsum rock and pre-saturated samples at 35,70 and $105 \mathrm{~d}$ of soaking using a hydraulic compression testing machine (Instron, UK, 5584 universal testing machine) with a displacement rate of $1 \mathrm{~mm} / \mathrm{min}$ and a loading rate of $0.5 \mathrm{~mm} / \mathrm{min}$. A circumferential extensometer was used to measure the radial strain of the specimens as shown in Figure 4.

\section{Flexural test (ASTM D 6272-10)}

Based on the various research studies performed on the flexural beam rock samples, various dimensions $(L \times W \times D)$ of the flexural rock samples were used (Table 1). In this study, the four-point bending test (ASTM, 2010b) with dimensions $(L \times W \times D)$ of $140 \mathrm{~mm} \times 40 \mathrm{~mm} \times 20 \mathrm{~mm}$ was performed as shown in Figure 4(b). The loading rate was selected to be $0.075 \mathrm{MPa} / \mathrm{s}$. The flexural strength $\left(\sigma_{\mathrm{f}}\right)$ of the samples was calculated using the equation

1. $\sigma_{\mathrm{f}}=\frac{P_{\max } \times L}{4 \times b \times(d)^{2}}$

where $\sigma_{\mathrm{f}}$ is the flexural strength (MPa); $P_{\max }$ is the load at a given point (maximum) on the load-deflection curve $(\mathrm{N}) ; L$ is the support span (mm); $b$ is the width of the tested beam $(\mathrm{mm})$; and $d$ is the depth of the tested beam (mm) as shown in Figure 4(b).

\section{Electrical conductivity}

A conductivity probe was used to measure the conductivity of the contaminated distilled water with dissoluble gypsum. The conductivity measuring range was from $0 \cdot 1$ to $1000 \mu \mathrm{S} / \mathrm{cm}$. The device was calibrated using different standard solutions. 
Geotechnical Research

Volume 6 Issue GR2
Vipulanandan $\boldsymbol{p}-\boldsymbol{q}$ model to predict the

effect of pressurised water on the

strengths of gypsum rock in Kurdistan

Region, Iraq

Mohammed and Salih

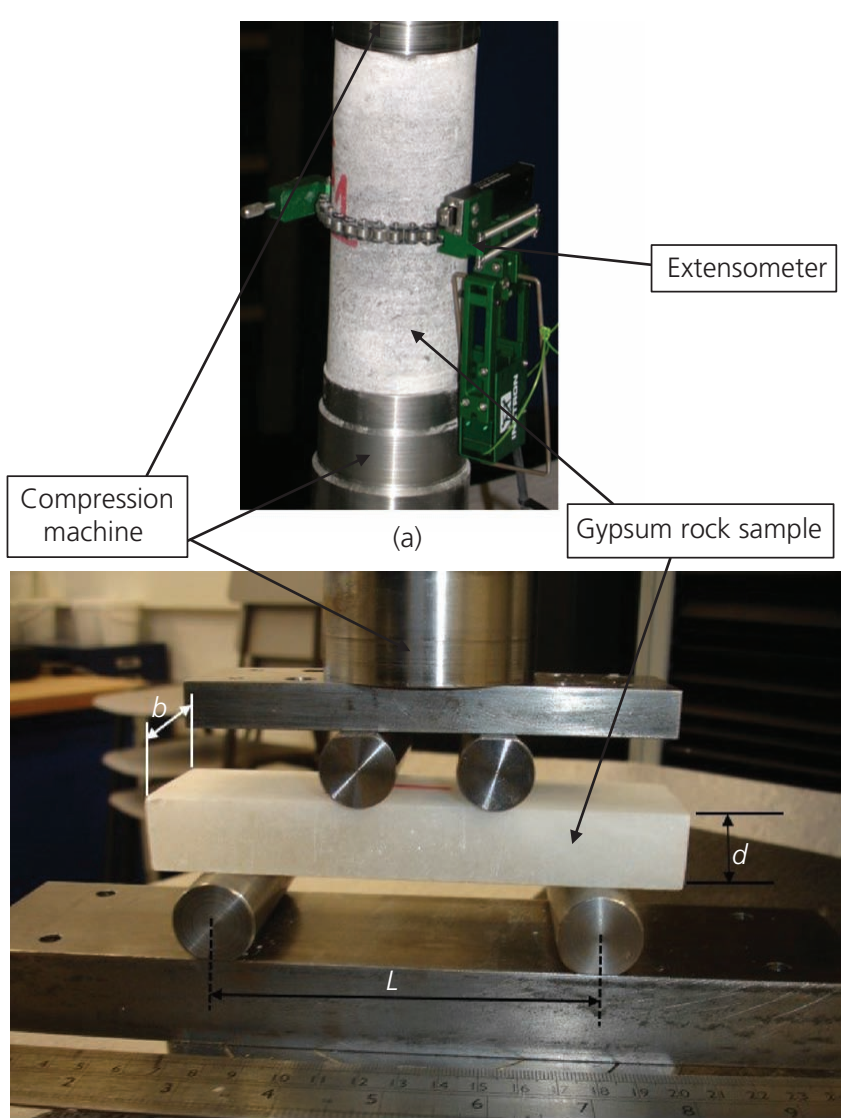

(b)

Figure 4. Experimental set-up for the (a) compression test and (b) four-point bending test for the gypsum rock samples (cylinders and beams)

\section{Comparison of model predictions}

In order to determine the accuracy of the model predictions, both the coefficients of determination $\left(R^{2}\right)$ and the root mean square error (RMSE) for the model predictions as defined in Equations 2 and 3 were quantified.

2.

$$
R^{2}=\left[\frac{\sum_{i}\left(x_{i}-\bar{x}\right)\left(y_{i}-\bar{y}\right)}{\sqrt{\sum_{i}\left(x_{i}-\bar{x}\right)^{2}} \times \sqrt{\sum_{i}\left(y_{i}-\bar{y}\right)^{2}}}\right]^{2}
$$

3. $\mathrm{RMSE}=\sqrt{\frac{\sum_{i=1}^{n}\left(y_{i}-x_{i}\right)^{2}}{N}}$

where $y_{i}$ are the actual test data; $x_{i}$ are the calculated data from the model; $\bar{y}$ is the mean of the actual test data; $\bar{x}$ is the mean of calculated data; and $N$ is the number of experimental data points.

\section{Results and discussion}

X-ray diffraction

The field rock sample contained gypsum $(2 \theta$ peaks at $14 \cdot 96,21 \cdot 00$, $26 \cdot 80,36 \cdot 68,39 \cdot 64,42 \cdot 52,50 \cdot 28$ and $\left.55 \cdot 48^{\circ}\right)$ and quartz $\left(\mathrm{SiO}_{2}\right)$ ( $2 \theta$ peaks at 60.02 and $76.21^{\circ}$ ) as shown in Figure 5. Similar results were obtained by Koukouzas and Vasilatos (2008). Based on the XRD test results, the GC in the field sample was $96 \%$.

\section{Thermogravimetric analysis}

Using TGA, the weight loss at the rate of weight change with temperature was obtained for field gypsum rock. Weight loss in gypsum rock was analysed in four temperature ranges as shown in Figure 6. The hemihydrate was formed between 100 and $200^{\circ} \mathrm{C}$ when the heating rate was $10^{\circ} \mathrm{C} / \mathrm{min}$, but complete conversion below $100^{\circ} \mathrm{C}$ occurred when heating was very slow. A few minutes of heating above $250^{\circ} \mathrm{C}$ or longer between 100 and $125^{\circ} \mathrm{C}$ resulted in the formation of soluble anhydrite $\left(\gamma-\mathrm{CaSO}_{4}\right)$; further heating around $360^{\circ} \mathrm{C}$ gave anhydrite (Khalil and Gad, 1972). Weight loss for the

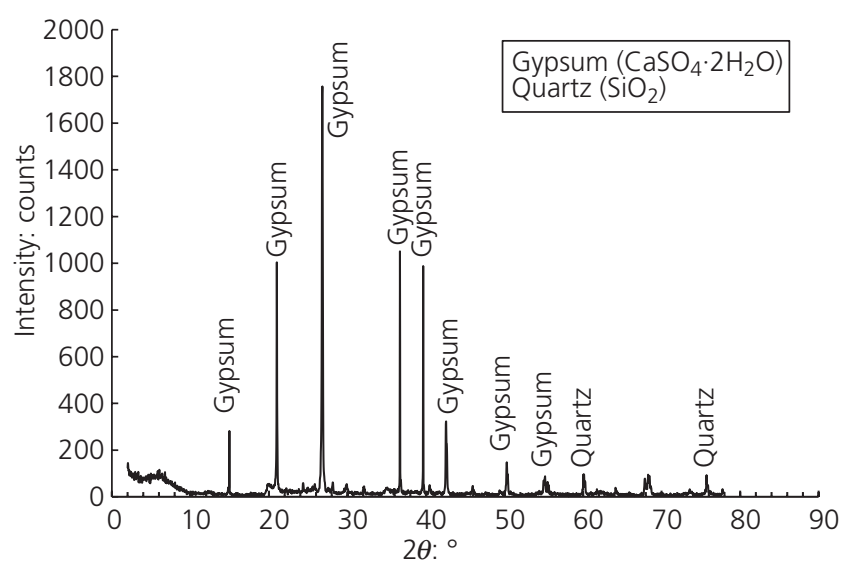

Figure 5. XRD pattern of the gypsum rock

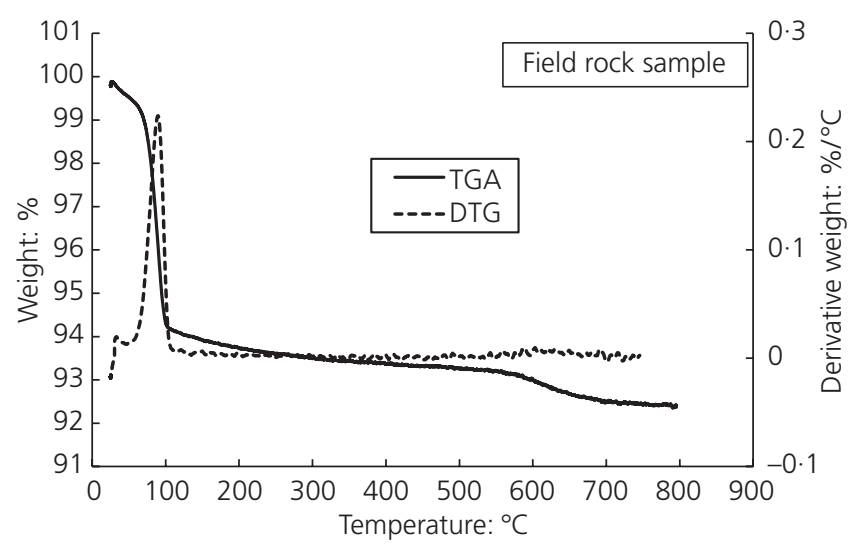

Figure 6. Weight loss obtained using TGA and DTG for the gypsum rock 
field gypsum rock between 25 and $120^{\circ} \mathrm{C}$ was $5 \cdot 70 \%$, and it was $0.75 \%$ when the temperature changed from 120 to $400^{\circ} \mathrm{C}$. The weight loss for gypsum rock was $0.39 \%$ when the temperature changed from 400 to $600^{\circ} \mathrm{C}$ as shown in Figure 7. The total weight loss for the gypsum rock at $800^{\circ} \mathrm{C}$ was $7 \cdot 53 \%$, as shown in Figure 6 .

\section{Gypsum content (\%)}

The EC is a good tool to measure the capacity of water to conduct electrical current; it is related to the concentration of gypsum dissolved in 1 litre of distilled water as shown in Figure 8. The EC of the water was used to determine the amount of the gypsum $(\mathrm{g} / \mathrm{l})$ dissolved in the distilled water. Distilled water does not contain dissolved gypsum so it does not conduct electricity and has an EC of zero, as shown in Figure 8. The EC of the distilled water contaminated with dissolved gypsum was recorded every $7 \mathrm{~d}$. The process of dissolution started from 0 up to $3 \mathrm{~g}$ of gypsum powder mixed with 1 litre of distilled water using an electrical blender. Based on the experimental data shown in Figure 8, the relationship in Equation 4 was used to predict the $\mathrm{GC}$ in grams per litre from the EC $(\mu \mathrm{S} / \mathrm{cm})$.

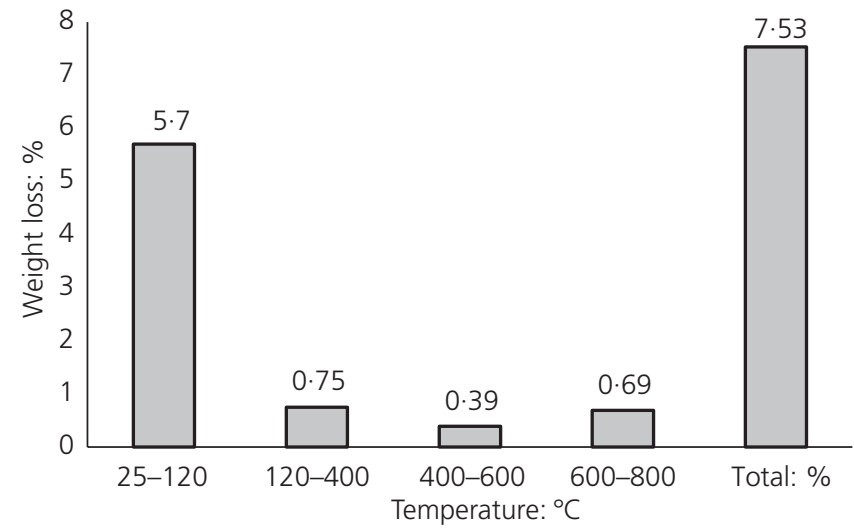

Figure 7. TGA test results for the gypsum rock

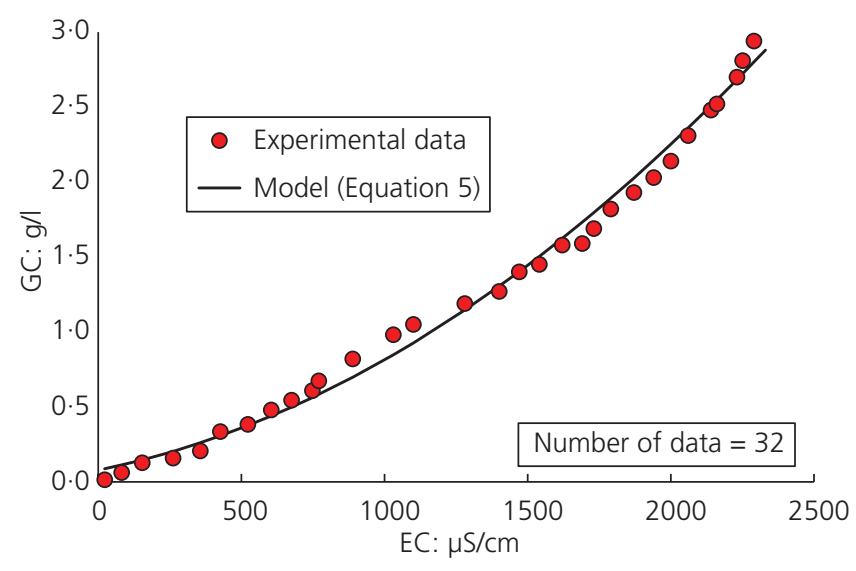

Figure 8. GC-EC relationship

$$
\begin{aligned}
& \mathrm{GC}(\mathrm{g} / \mathrm{l})=6 \times 10^{-4} \times(\mathrm{EC})^{2}+4 \times 10^{-4} \times \mathrm{EC}+0.08 \\
& R^{2}=0.99 \text { for }(0 \leq \mathrm{GC}(\mathrm{g} / \mathrm{l}) \leq 3)
\end{aligned}
$$

4.

According to the conducted relationship in Figure 8, the measured conductivity amount will be deducted from the total GC of soaked samples. After that, the remaining GC is achieved due to the measured dissolved gypsum per cent.

\section{Weight loss due to saturation (\%)}

Using the $0.001 \mathrm{~g}$ electrical balance, the gypsum loss at the rate of weight loss with soaking time for pre-saturated samples at various confined water pressures was measured. GC (\%) decreased with increasing soaking time and confined water pressure as shown in Figure 9. GC decreased from 96 to $89 \cdot 5 \%$, a $6.8 \%$ reduction, when the sample was soaked for $105 \mathrm{~d}$ under $0 \mathrm{MPa}$ of confined water pressure as shown in Figure 9. GC decreased from 96 to $85 \%$, an $11.5 \%$ reduction, when the rock sample was soaked for $105 \mathrm{~d}$ in distilled water under $0.5 \mathrm{MPa}$ of confined water pressure as shown in Figure 9. The weight loss represented by the amount of gypsum lost increased by 37,43 and $70 \%$ when the confining water pressure increased to $0 \cdot 2,0 \cdot 35$ and $0.5 \mathrm{MPa}$ at $105 \mathrm{~d}$ of soaking, respectively, as shown in Figure 9. This also indicates that the rate of the gypsum dissolved increased with increasing confining water pressure.

\section{Compressive strength}

The compressive strength and the density of the normal gypsum rock samples were compared with 102 data for the different types of rock collected from literature as shown in Figure 2. With an increase in the soaking time, the compressive strength decreased. For example, it decreased from 19.6 MPa (2843 pounds per square inch (psi)) to $12 \cdot 1 \mathrm{MPa}(1755 \mathrm{psi})$, which is a $38 \%$ reduction, at $35 \mathrm{~d}$ of soaking at $0 \mathrm{MPa}$ of confined water pressure as summarised in Table 2. The compressive strength decreased from 19.6 MPa

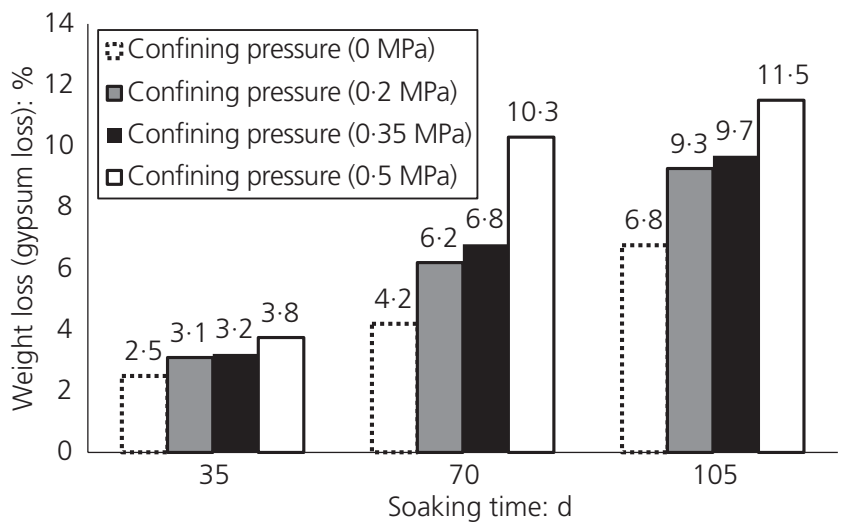

Figure 9. Variation in weight loss for the gypsum rock plotted against soaking time for compression test samples with different confined water pressures 
(2843 psi) to $6.3 \mathrm{MPa}(914 \mathrm{psi}$ ), which is a $68 \%$ reduction, at $105 \mathrm{~d}$ of soaking at $0 \mathrm{MPa}$ of confined water pressure as summarised in Table 2. With the increase in the water pressure, the compressive strength decreased. The compressive strength decreased from $6.3 \mathrm{MPa}$ (914 psi) to $2 \mathrm{MPa}(290 \mathrm{psi}$ ), which is a $68 \%$ reduction, at $105 \mathrm{~d}$ of soaking when the confined water pressure increased from 0 to $0.5 \mathrm{MPa}$ (73 psi), as shown in Figure 10 .

With the increase in soaking time, the initial modulus of elasticity decreased. It decreased from 5297 to 3335 and $1600 \mathrm{MPa}, 37$ and $70 \%$ reductions, at 35 and $105 \mathrm{~d}$ of soaking, respectively, at $0 \mathrm{MPa}$ of confined water pressure, as shown in Figure 11. Increasing the confined water pressure from 0 to $0.5 \mathrm{MPa}$ decreased the initial modulus of elasticity of the samples by 43 and $50 \%$ at 35 and $105 \mathrm{~d}$ of soaking, respectively, as shown in Figure 11. The initial modulus of elasticity of the gypsum rocks decreased with increasing soaking time and confined water pressure, as shown in Figure 11.

\section{Stress-strain behaviour modelling}

In this study, the pre-saturated gypsum rock with four different confining water pressures after various soaking times exhibited a strain-softening behaviour, as shown in Figures 12 and 13.

\section{Vipulanandan $p-q$ model}

Based on experimental results, the model proposed by Vipulanandan and Paul (1990) was used to predict the stress-strain behaviour of gypsum rock with four different confining water pressures at different soaking times (Equation 5). The model is defined as follows

Table 2. Stress-strain model parameters for the gypsum rock

\begin{tabular}{|c|c|c|c|c|c|c|c|c|c|c|c|c|c|}
\hline \multirow[b]{2}{*}{$\begin{array}{l}\text { Confined water } \\
\text { pressure: MPa }\end{array}$} & \multirow[b]{2}{*}{$\begin{array}{l}\text { Soaking } \\
\text { time: } d\end{array}$} & \multirow[b]{2}{*}{ GC: $\%$} & \multicolumn{6}{|c|}{ Vipulanandan $p-q$ model (Equation 5) } & \multicolumn{5}{|c|}{$\beta$ model (Equation 6) } \\
\hline & & & $\begin{array}{c}\sigma_{\mathrm{c}}: \\
\mathrm{MPa}\end{array}$ & $\varepsilon_{\mathrm{c}}: \%$ & $p$ & $q$ & $\begin{array}{l}\text { RMSE: } \\
\text { MPa }\end{array}$ & $R^{2}$ & $\begin{array}{l}\sigma_{\mathrm{c}}: \\
\mathrm{MPa}\end{array}$ & $\varepsilon_{\mathrm{c}}: \%$ & $\beta$ & $\begin{array}{l}\text { RMSE: } \\
\text { MPa }\end{array}$ & $R^{2}$ \\
\hline Field sample & 0 & $\begin{array}{c}96 \cdot 0 \pm \\
0.4\end{array}$ & $\begin{array}{c}19.6 \pm \\
0.9\end{array}$ & $\begin{array}{c}0.38 \pm \\
0.01\end{array}$ & $\begin{array}{c}1 \cdot 81 \pm \\
0.2\end{array}$ & $\begin{array}{c}0.84 \pm \\
0.02\end{array}$ & $0 \cdot 204$ & 0.99 & $\begin{array}{c}19 \cdot 8 \pm \\
1 \cdot 3\end{array}$ & $\begin{array}{c}0.38 \pm \\
0.02\end{array}$ & $\begin{array}{c}3 \cdot 38 \pm \\
1\end{array}$ & $0 \cdot 443$ & 0.99 \\
\hline \multirow[t]{2}{*}{0} & 35 & $\begin{array}{c}93.6 \pm \\
0.6\end{array}$ & $\begin{array}{c}12 \cdot 1 \pm \\
1\end{array}$ & $\begin{array}{c}0.53 \pm \\
0.02\end{array}$ & $\begin{array}{c}1 \cdot 5 \pm \\
0.1\end{array}$ & $\begin{array}{c}1 \cdot 13 \pm \\
0.01\end{array}$ & $0 \cdot 134$ & 0.99 & $\begin{array}{c}12 \cdot 4 \pm \\
1 \cdot 5\end{array}$ & $\begin{array}{c}0.55 \pm \\
0.03\end{array}$ & $\begin{array}{l}3 \cdot 12 \pm \\
1 \cdot 3\end{array}$ & $0 \cdot 330$ & 0.99 \\
\hline & 105 & $\begin{array}{c}89 \cdot 5 \pm \\
0.4\end{array}$ & $\begin{array}{r}6 \cdot 3 \pm \\
1 \cdot 5\end{array}$ & $\begin{array}{r}0.41 \pm \\
0.01\end{array}$ & $\begin{array}{l}1 \cdot 1 \pm \\
0 \cdot 1\end{array}$ & $\begin{array}{c}1.30 \pm \\
0.02\end{array}$ & 0.051 & 0.99 & $\begin{array}{c}5 \cdot 2 \pm \\
1 \cdot 6\end{array}$ & $\begin{array}{c}0.42 \pm \\
0.01\end{array}$ & $\begin{array}{c}2 \cdot 55 \pm \\
1 \cdot 2\end{array}$ & 0.237 & 0.98 \\
\hline \multirow[t]{2}{*}{$0 \cdot 20$} & 35 & $\begin{array}{c}93 \cdot 0 \pm \\
0.5\end{array}$ & $\begin{array}{c}7 \cdot 8 \pm \\
2\end{array}$ & $\begin{array}{c}0.49 \pm \\
0.03\end{array}$ & $\begin{array}{c}1 \cdot 3 \pm \\
0 \cdot 2\end{array}$ & $\begin{array}{c}0.67 \pm \\
0.03\end{array}$ & 0.066 & 0.99 & $\begin{array}{c}7 \cdot 8 \pm \\
2 \cdot 1\end{array}$ & $\begin{array}{c}0.46 \pm \\
0.05\end{array}$ & $\begin{array}{l}3 \pm \\
1 \cdot 1\end{array}$ & $0 \cdot 190$ & 0.99 \\
\hline & 105 & $\begin{array}{c}87 \cdot 1 \pm \\
0.6\end{array}$ & $\begin{array}{c}4 \cdot 2 \pm \\
1 \cdot 3\end{array}$ & $\begin{array}{c}0.33 \pm \\
0.01\end{array}$ & $\begin{array}{l}1 \pm \\
0.12\end{array}$ & $\begin{array}{c}0.47 \pm \\
0.04\end{array}$ & 0.054 & 0.99 & $\begin{array}{c}4 \cdot 2 \pm \\
1.6\end{array}$ & $\begin{array}{c}0.32 \pm \\
0.03\end{array}$ & $\begin{array}{l}2 \pm \\
1 \cdot 12\end{array}$ & $0 \cdot 111$ & 0.99 \\
\hline \multirow[t]{2}{*}{$0 \cdot 35$} & 35 & $\begin{array}{c}92.9 \pm \\
0.8\end{array}$ & $\begin{array}{c}6 \cdot 4 \pm \\
2\end{array}$ & $\begin{array}{c}0.40 \pm \\
0.03\end{array}$ & $\begin{array}{c}1.32 \pm \\
0.14\end{array}$ & $\begin{array}{c}0.87 \pm \\
0.02\end{array}$ & 0.068 & 0.99 & $\begin{array}{c}6 \cdot 4 \pm \\
2 \cdot 1\end{array}$ & $\begin{array}{c}0.41 \pm \\
0.04\end{array}$ & $\begin{array}{c}2 \cdot 57 \pm \\
1 \cdot 3\end{array}$ & 0.146 & 0.98 \\
\hline & 105 & $\begin{array}{c}86.7 \pm \\
0.4\end{array}$ & $\begin{array}{c}3 \cdot 6 \pm \\
1 \cdot 3\end{array}$ & $\begin{array}{c}0.34 \pm \\
0.01\end{array}$ & $\begin{array}{c}1 \cdot 2 \pm \\
0.2\end{array}$ & $\begin{array}{c}0.97 \pm \\
0.03\end{array}$ & $0 \cdot 025$ & 0.99 & $\begin{array}{c}3 \cdot 6 \pm \\
1.7\end{array}$ & $\begin{array}{c}0.35 \pm \\
0.03\end{array}$ & $\begin{array}{c}2 \cdot 41 \\
1.5\end{array}$ & $0 \cdot 103$ & 0.99 \\
\hline \multirow[t]{2}{*}{0.50} & 35 & $\begin{array}{c}92 \cdot 4 \pm \\
0.2\end{array}$ & $\begin{array}{c}4.9 \pm \\
1.6\end{array}$ & $\begin{array}{c}0.35 \pm \\
0.02\end{array}$ & $\begin{array}{c}1 \cdot 70 \pm \\
0.1\end{array}$ & $\begin{array}{c}0.70 \pm \\
0.01\end{array}$ & 0.058 & 0.99 & $\begin{array}{c}4 \cdot 9 \pm \\
1.8\end{array}$ & $\begin{array}{r}0.36 \pm \\
0.02\end{array}$ & $\begin{array}{c}2 \cdot 22 \pm \\
1 \cdot 3\end{array}$ & $0 \cdot 133$ & 0.98 \\
\hline & 105 & $\begin{array}{c}85.0 \pm \\
0.6\end{array}$ & $\begin{array}{c}2 \cdot 0 \pm \\
1 \cdot 3\end{array}$ & $\begin{array}{c}0.31 \pm \\
0.01\end{array}$ & $\begin{array}{r}0.8 \pm \\
0.15\end{array}$ & $\begin{array}{c}0.56 \pm \\
0.02\end{array}$ & 0.039 & 0.99 & $\begin{array}{c}3 \cdot 2 \pm \\
1 \cdot 5\end{array}$ & $\begin{array}{c}0.30 \pm \\
0.02\end{array}$ & $\begin{array}{c}2 \cdot 35 \pm \\
1 \cdot 4\end{array}$ & 0.065 & 0.99 \\
\hline
\end{tabular}

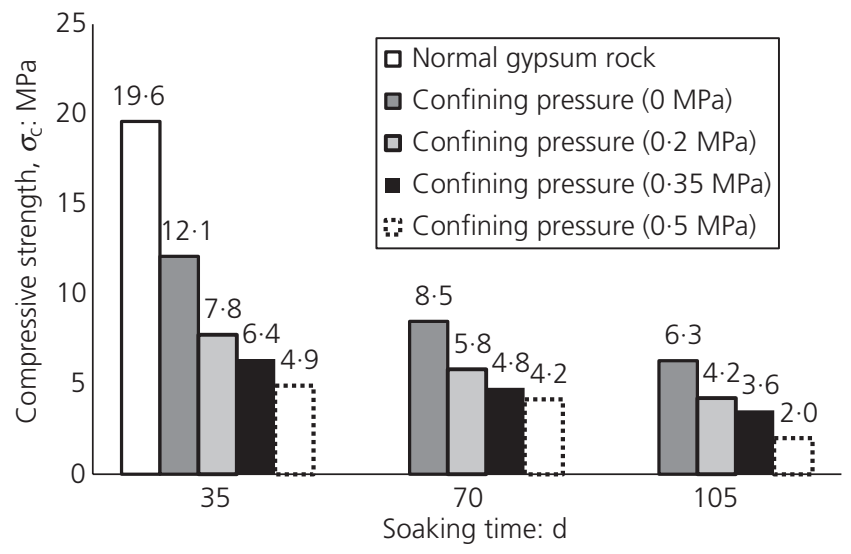

Figure 10. Variation in compressive strength of the gypsum rock plotted against soaking time with different confined pressures

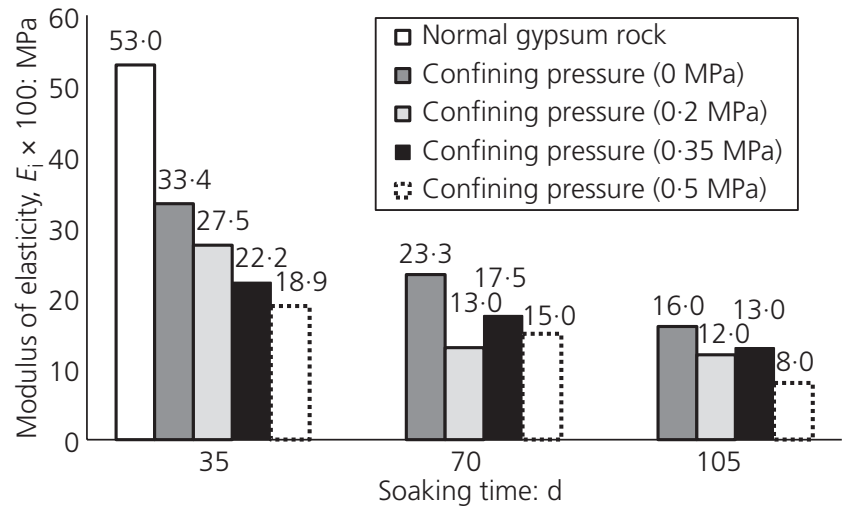

Figure 11. Variation in initial compressive modulus of the gypsum rock plotted against soaking time for compression test samples with different confined pressures 
Vipulanandan $p-q$ model to predict the

effect of pressurised water on the

strengths of gypsum rock in Kurdistan

Region, Iraq

Mohammed and Salih

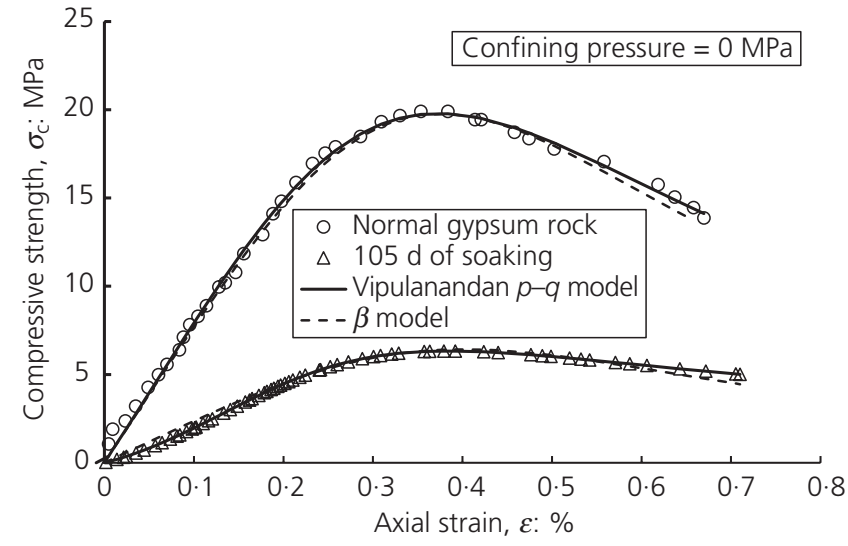

Figure 12. Comparison of experimental stress-strain and model predictions for the gypsum rock

5. $\sigma=\left[\frac{\varepsilon / \varepsilon_{\mathrm{c}}}{q+(1-p-q)\left(\varepsilon / \varepsilon_{\mathrm{c}}\right)+p\left(\varepsilon / \varepsilon_{\mathrm{c}}\right)^{(p+q) / p}}\right] \times \sigma_{\mathrm{c}}$
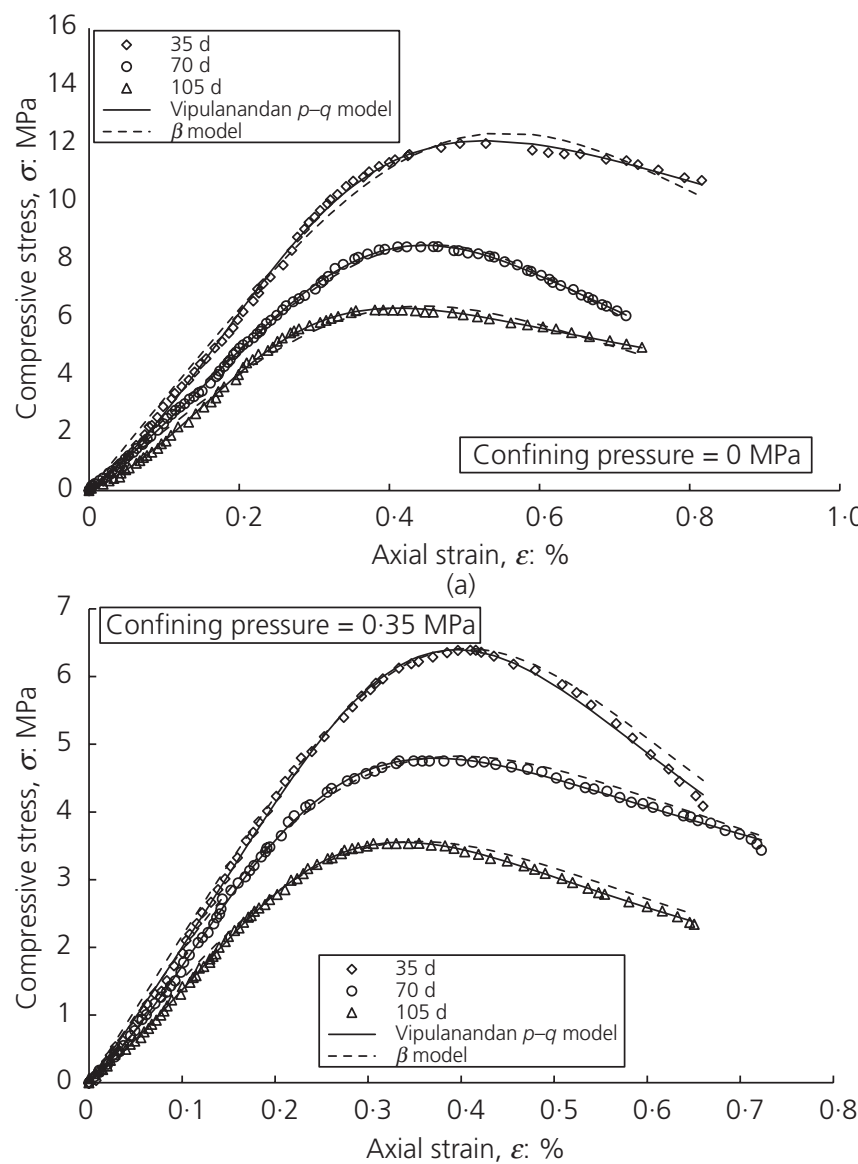

(c) where $\sigma$ is the compressive stress, $\varepsilon$ is the axial strain (\%), $\sigma_{\mathrm{c}}$ and $\varepsilon_{\mathrm{c}}$ are the compressive strength and the corresponding strain, respectively, and $p$ and $q$ are material parameters.

The parameter $q$ was defined as the ratio of the secant modulus at peak stress to the initial tangent modulus. The parameter $p$ was obtained by minimising the error in the predicted stress-strain relationship. Hence, the parameters $p$ and $q$ in Equation 5 were determined based on the stress-strain behaviour of gypsum rock with different soaking times, confined water pressures, RMSEs and coefficients of determination $R^{2}$ and are summarised in Table 2. The parameters $p$ and $q$ are influenced by GC (\%), as summarised in Table 2. The shape of the stress-strain curve can be changed based on the $p$ and $q$ values as shown in Figure 14(a).

\section{PARAMETER $p$}

For gypsum rock with different percentages of $\mathrm{GC}$, the parameter $p$ was in the range $0 \cdot 80-1 \cdot 81$, as summarised in Table 2 . Hence, the descending part of the strain-softening stress-strain relationship for the saturated samples was steeper compared to that for the normal gypsum rock samples. For the normal gypsum rock samples with

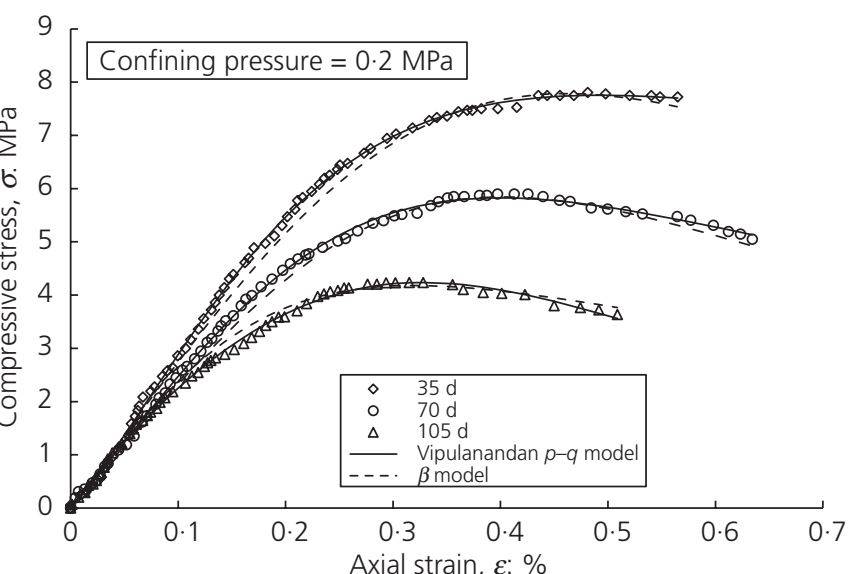

(b)

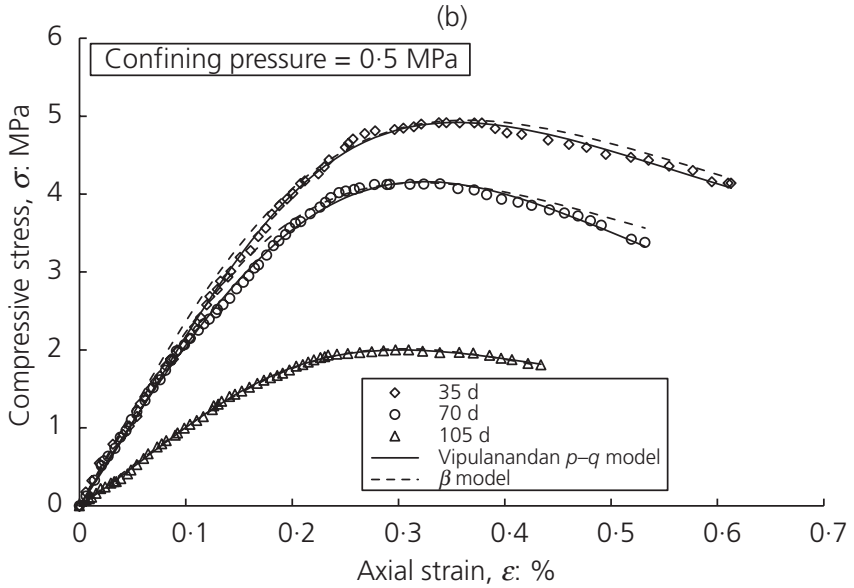

(d)

Figure 13. Comparison of experimental stress-strain and models prediction for the gypsum rock with different confined water pressures: (a) $P=0 \mathrm{MPa}$; (b) $P=0.2 \mathrm{MPa}$; (c) $P=0.35 \mathrm{MPa}$; (d) $P=0.5 \mathrm{MPa}$ 


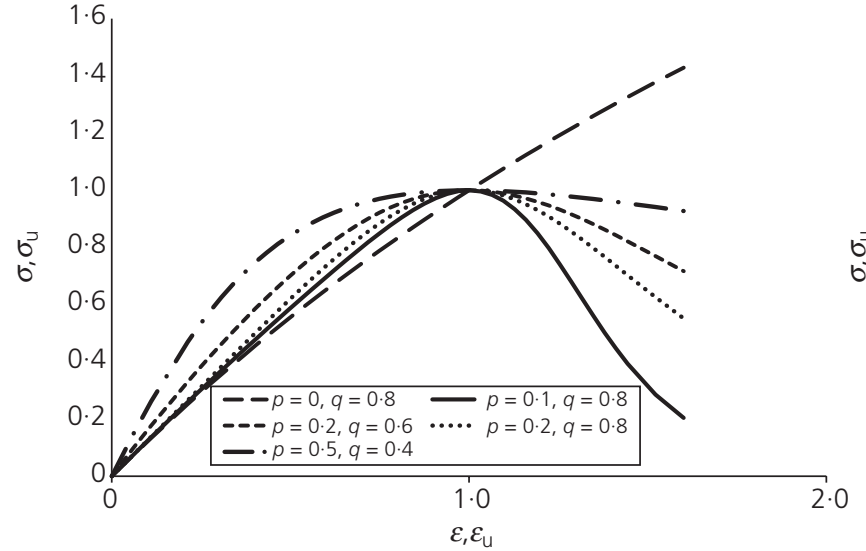

(a)

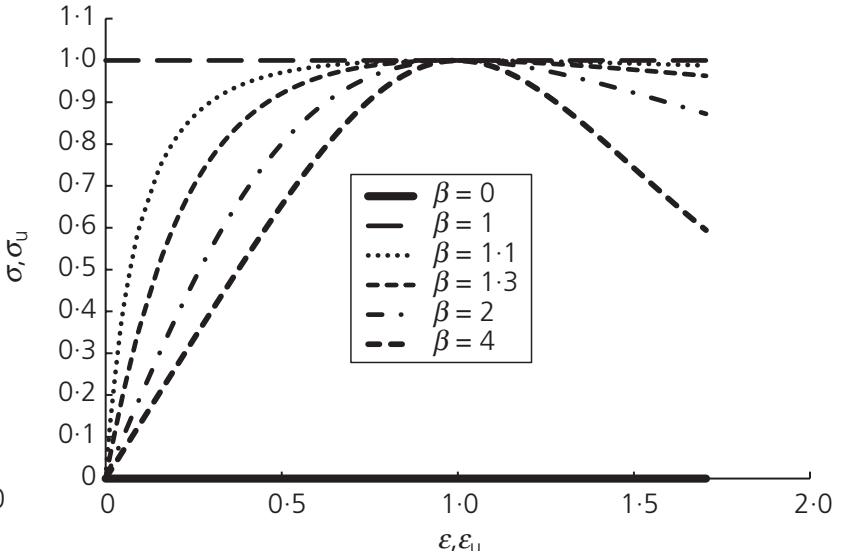

(b)

Figure 14. Compressive stress-strain relationships: (a) Vipulanandan $p-q$ model and (b) $\beta$ model

$96 \% \mathrm{GC}, p$ was 1.81 and was reduced to 0.8 when the $\mathrm{GC}$ was $85 \%$, as summarised in Table 2. The parameter $p$ and GC were correlated using Equation 8, and model parameters, RMSE and coefficients of determination $\left(R^{2}\right)$ are summarised in Table 2.

\section{PARAMETER $q$}

This parameter represents the non-linear behaviour of the gypsum rock up to the peak stress. For gypsum rock with different percentages of GC, the parameter $q$ was in the range $0 \cdot 47-1 \cdot 30$, as summarised in Table 2, and indicates that the material behaviour is more linear with soaking time and confining water pressure. For the normal gypsum rock sample with $96 \%$ GC, $q$ was 0.84 and was reduced to 0.56 when the $\mathrm{GC}$ was $85 \%$, as summarised in Table 2. The parameter $q$ and GC were correlated using Equation 8, and model parameters, RMSE and coefficient of determination $\left(R^{2}\right)$ are summarised in Table 2 .

\section{$\beta$ method}

Ezeldin and Balaguru (1992) proposed an analytical equation (Equation 7) to generate the stress-strain curve for the normal strength of steel-fibre-reinforced concrete based on the equation proposed by Carreira and Chu (1985) for uniaxial compression of plain concrete. This equation involves the material parameter $\beta$, which is the slope of the inflection point at the descending branch of the shear stress relationship.

6.

$$
\sigma=\left[\frac{\beta\left(\varepsilon / \varepsilon_{\mathrm{c}}\right)}{\beta-1+\left(\varepsilon / \varepsilon_{\mathrm{c}}\right)^{\beta}}\right] \times \sigma_{\mathrm{c}}
$$

where $\sigma$ is the compressive stress, $\sigma_{\mathrm{c}}$ and $\varepsilon_{\mathrm{c}}$ are the compressive strength and the corresponding strain, respectively, and $\beta$ is a material parameter.

The stress-strain relationship for gypsum rock in different soaking times and four different confined water pressures and the model predictions are shown in Figures 11 and 12.

\section{PARAMETER $\beta$}

For the normal gypsum rock sample, parameter $\beta$ was $3 \cdot 38$. It decreased to 2.55 when the sample was kept in distilled water for $105 \mathrm{~d}$, as summarised in Table 2 . The parameter $\beta$ varied from 2 to 3 when the soaking time varied between 0 and $105 \mathrm{~d}$ under confined water pressure varying from 0 to $0.5 \mathrm{MPa}$, as summarised in Table 2. The shape of the stress-strain curve can be changed based on the $\beta$ value, as shown in Figure 14(b).

\section{Compressive strength $\left(\sigma_{\mathrm{c}}\right)$ \\ Normal gypsum rock}

The compressive strength $\left(\sigma_{\mathrm{c}}\right)$ of the normal gypsum rock sample with a density of $2.3 \mathrm{~g} / \mathrm{cm}^{3}$ and GC of $96 \%$ was $19.6 \mathrm{MPa}$, as shown in Figure 11. The compressive stress-strain behaviour of the normal gypsum rock sample was modelled using the Vipulanandan $p-q$ model (Equation 5). The coefficient of determination $\left(R^{2}\right)$ was 0.99 , as summarised in Table 1 . The RMSE was $0.204 \mathrm{MPa}$, as summarised in Table 2. The model parameters $p$ and $q$ for normal gypsum rock were 1.81 and 0.84 , respectively, as summarised in Table 1 . The Vipulanandan $p-q$ model (Equation 5) predicted the stress-strain behaviour of the normal gypsum rock sample very well, as shown in Figure 12.

\section{Pre-saturated samples} CONFINED WATER PRESSURE OF $0 \mathrm{MPa}$

The compressive stress-strain behaviour of the pre-saturated gypsum rock with three different soaking times of 35, 70 and $105 \mathrm{~d}$ was modelled using the Vipulanandan $p-q$ model (Equation 5). The coefficients of determination $\left(R^{2}\right)$ were 0.99 , as summarised in Table 2. The RMSE varied between 0.051 and $0.134 \mathrm{MPa}$, as summarised in Table 2. The model parameter $p$ for pre-saturated gypsum rock with three different soaking times varying between 1.1 and 1.5 is summarised in Table 2 . The model parameter $q$ for pre-saturated gypsum rock with three different soaking times varying between $1 \cdot 13$ and 1.30 is summarised in Table 2. 


\section{CONFINED WATER PRESSURE OF $0.5 \mathrm{MPa}$}

The compressive strength $\left(\sigma_{\mathrm{c}}\right)$ of the pre-saturated gypsum rock sample decreased by $50 \%$ when the sample was soaked in distilled water for $35 \mathrm{~d}$ under $0.5 \mathrm{MPa}$ of confined water pressure, as summarised in Table 2. The compressive stress-strain behaviour of the pre-saturated gypsum rock with three different soaking times of 35,70 and $105 \mathrm{~d}$ was modelled using the Vipulanandan $p-q$ model (Equation 5). The coefficients of determination $\left(R^{2}\right)$ for all samples were 0.99 , as summarised in Table 2 . The RMSE varied between 0.025 and $0.068 \mathrm{MPa}$, as summarised in Table 2. The model parameter $p$ for gypsum rock with three different soaking times varied between 0.8 and 1.7 , as summarised in Table 2 . The model parameter $q$ for the pre-saturated gypsum rock with three different soaking times varied between 0.58 and 0.97 , as summarised in Table 2. The Vipulanandan $p-q$ model (Equation 5) predicted the stress-strain behaviour of the pre-saturated gypsum rock very well (Figure 12(d)).

\section{LINEAR MODEL PARAMETERS}

The model parameters $\sigma_{\mathrm{c}}, \varepsilon_{\mathrm{c}}, p, q$ and $\beta$ and initial modulus of elasticity $\left(E_{\mathrm{i}}\right)$ were influenced by the GC $(\%)$. It is being proposed to relate the model parameters to the independent variables (GC $(\%)$ ), soaking time $(t)(\mathrm{d})$ and confining water pressure $(P)(\mathrm{MPa}))$ using a linear relationship as proposed.

The effects of GC, soaking time and confining water pressure were separated as follows

model parameters $\left(\sigma_{\mathrm{c}}, \varepsilon_{\mathrm{c}}, p, q, \beta, E_{i}\right)$

7. $=k+a \times(\mathrm{GC})+b(t)+c(P)$

where $k$ is the initial model parameter for gypsum rock (normal gypsum rock) and $a, b$ and $c$ are the linear model (LM) parameters. The LM parameters were obtained from multiple regression analyses using the least-squares method. The LM parameters and coefficient of determination $\left(R^{2}\right)$ and RMSE are summarised in Table 3.

Stress-strain data from all the finished tests in Table 2 are utilised to produce the corresponding $p$ and $q$ values by regression analysis following Equation 5. Then, these $p, q, \sigma_{\mathrm{c}}$ and $\varepsilon_{\mathrm{c}}$ values are used to train Equation 7 to get the value of the parameters $k$, $a, b$ and $c$. Secondly, for any other untested gypsum sample provided with GC, soaking time and confining water pressure, the $p, q, \sigma_{\mathrm{c}}$ and $\varepsilon_{\mathrm{c}}$ values of that untested gypsum sample will be derived by applying those values of $k, a, b$ and $c$ obtained in the first step into Equation 7. Finally, these new $p, q, \sigma_{\mathrm{c}}$ and $\varepsilon_{\mathrm{c}}$ values can be used to predict the stress-strain curve of that untested gypsum sample by following Equation 5 .

\section{Flexural strength test}

\section{Volume loss (\%)}

A $0.01 \mathrm{~mm}$ digital vernier calliper was used to measure the volume of the flexural gypsum rock beams with dimensions $(L \times W \times D)$ of $140 \mathrm{~mm} \times 40 \mathrm{~mm} \times 20 \mathrm{~mm}$. The rate of volume change with soaking time for pre-saturated samples at various confined water pressures was measured. Volume loss in saturated gypsum rock at different confined water pressures was evaluated in three time interval ranges, as shown in Figure 15. The volume reductions (\%) of the gypsum rock at $0 \mathrm{MPa}$ confined water pressure were $2 \cdot 2,4 \cdot 7$ and $7 \cdot 3$ after 35,70 and $105 \mathrm{~d}$ of soaking, respectively, as shown in Figure 13. The volume loss of the samples increased with increasing confining water pressure at the same soaking time, as shown in Figure 16. Based on the test results, the flexural strength of the samples decreased by $33 \%$ for a soaking time of $105 \mathrm{~d}$ at $0 \cdot 5 \mathrm{MPa}$ of confined water pressure, as shown in Figure 16.

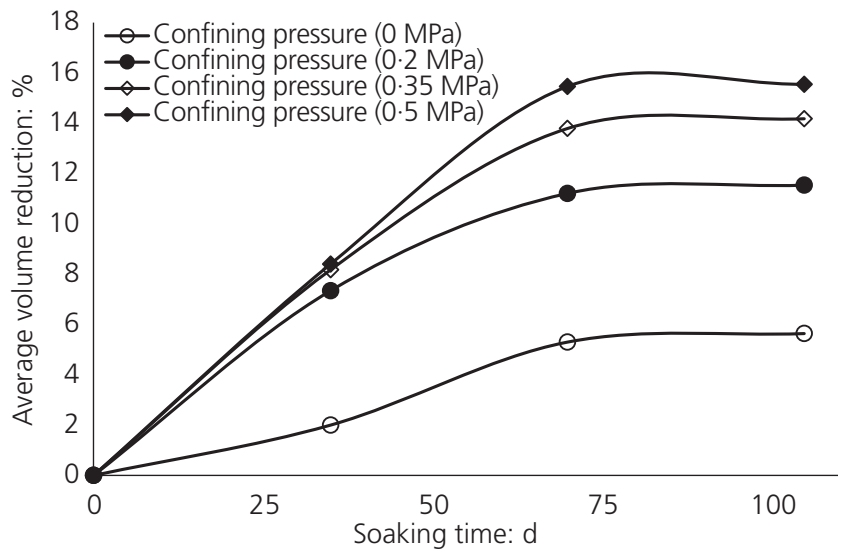

Figure 15. Variation in volume reduction of the gypsum rock plotted against soaking time for flexural test samples with different confined water pressures

Table 3. Linear compression and flexural strength model (Equation 8) parameters for the gypsum rock

\begin{tabular}{|c|c|c|c|c|c|c|c|c|}
\hline & Model parameters & $k$ & $a$ & $b$ & $c$ & Number of data & RMSE & $R^{2}$ \\
\hline \multirow[t]{5}{*}{ Equation 5} & $p$ & $2 \cdot 1$ & -0.003 & -0.007 & -0.41 & 12 & 0.081 & 0.88 \\
\hline & $q$ & $-12 \cdot 9$ & $0 \cdot 14$ & 0.013 & -0.27 & 13 & 0.079 & 0.87 \\
\hline & $\sigma_{\mathrm{c}}: \mathrm{MPa}$ & $81 \cdot 7$ & -0.73 & $-0 \cdot 11$ & $-11 \cdot 5$ & 12 & 0.311 & 0.96 \\
\hline & $\varepsilon_{c}: \%$ & $2 \cdot 22$ & -0.017 & -0.003 & -0.35 & 11 & 0.018 & 0.89 \\
\hline & $E_{\mathrm{i}}: \mathrm{MPa}$ & 42974 & -398 & -57 & -4684 & 13 & 230 & 0.95 \\
\hline \multirow[t]{3}{*}{ Equation 6} & $\sigma_{\mathrm{c}}: \mathrm{MPa}$ & 109 & $-1 \cdot 0$ & $-0 \cdot 13$ & $-13 \cdot 2$ & 12 & $0 \cdot 380$ & 0.94 \\
\hline & $\varepsilon_{\subset}: \%$ & 1.76 & -0.012 & -0.002 & $-0 \cdot 36$ & 11 & 0.020 & 0.88 \\
\hline & $\beta$ & 22.5 & -0.20 & -0.02 & $-2 \cdot 26$ & 12 & 0.060 & 0.97 \\
\hline
\end{tabular}


Vipulanandan $p-q$ model to predict the

effect of pressurised water on the

strengths of gypsum rock in Kurdistan

Region, Iraq

Mohammed and Salih

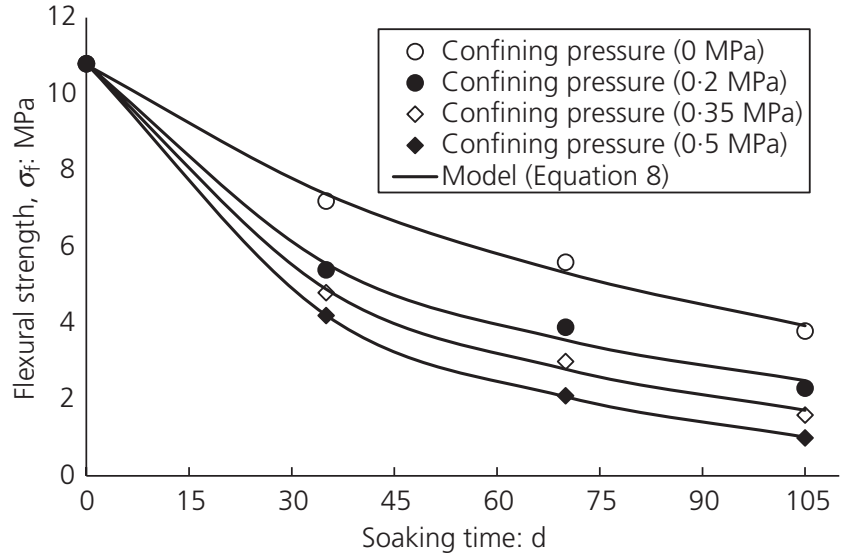

Figure 16. Relationship between flexural strength of the gypsum rock plotted against soaking time with different confined water pressures

Two- and three-parameter hyperbolic relationships (Equation 8) have been used for decades to correlate the changes in material properties with and without additives (Vipulanandan and Krishan, 1993; Vipulanandan and Mohammed, 2015a, 2015b).

The variation in flexural strength with soaking time was represented using the proposed hyperbolic model (Equation 8) and the parameters; the coefficient of determination $\left(R^{2}\right)$ and RMSE are summarised in Table 4.

8. $\sigma_{\mathrm{f}}-\sigma_{\mathrm{fo}}=\frac{\mathrm{GC}(\%)}{A+B \times \mathrm{GC}(\%)}$

where $\sigma_{\mathrm{f}}$ is the flexural strength (MPa), $\sigma_{\mathrm{fo}}$ is the initial flexural strength (normal gypsum rock sample) (MPa) and $A$ and $B$ are the flexural strength hyperbolic model parameters.

Correlation between compressive and flexural strength Based on the test results of the variation in flexural strength $\left(\sigma_{\mathrm{f}}\right)$ with the compressive strength $\left(\sigma_{\mathrm{c}}\right)$, Figure 17 is represented by the following non-linear hyperbolic relationship between flexural strength and compressive strength for the gypsum rocks.

9. $\quad \sigma_{\mathrm{f}}=\frac{\sigma_{\mathrm{c}}}{1.40+0.02 \times \sigma_{\mathrm{c}}} \quad R^{2}=0.98$

Table 4. Non-linear flexural strength model parameters (Equation 8) for the gypsum rock

\begin{tabular}{|cccccc|}
$\begin{array}{l}\text { Confined water } \\
\text { pressure: MPa }\end{array}$ & $\sigma_{\text {fo }}$ & $\boldsymbol{A}$ & $\boldsymbol{B}$ & $\mathrm{RMSE}$ & $\boldsymbol{R}^{\mathbf{2}}$ \\
\hline 0 & 10.8 & 0.09 & 7.83 & 0.180 & 0.99 \\
0.2 & 10.8 & 0.08 & 3.72 & 0.213 & 0.99 \\
0.35 & 10.8 & 0.08 & 3.12 & 0.127 & 0.99 \\
0.50 & 10.8 & 0.07 & 2.60 & 0.016 & 0.99 \\
\hline
\end{tabular}

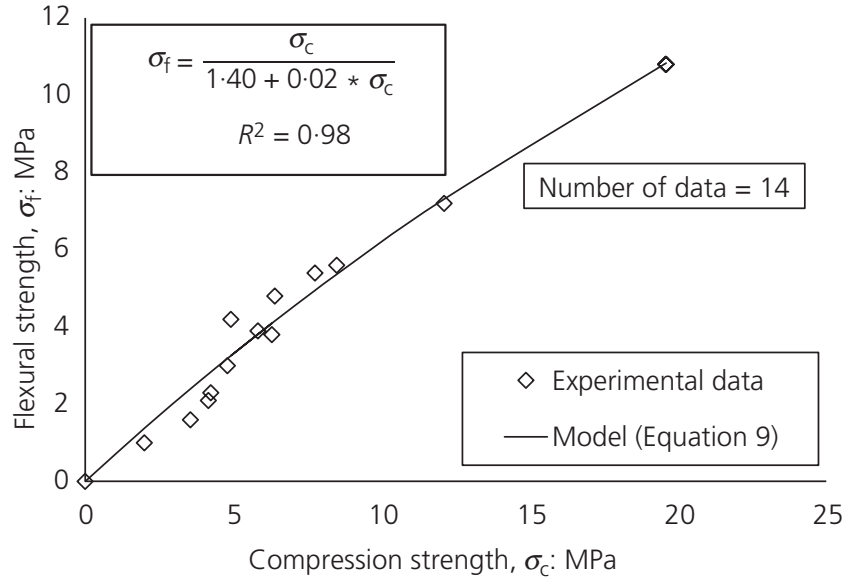

Figure 17. Relationship between compression strength and flexural strength of the gypsum rock

\section{Conclusions}

In this study, the effect of soaking time and confined water pressure of pre-saturated gypsum rock was characterised and quantified. Based on the experimental and analytical data and the compressive and flexural strength behaviour of the gypsum rocks, the following conclusions are advanced.

- Based on the TGA test results, the highest weight loss of the sample was observed between 25 and $120^{\circ} \mathrm{C}$, which was $5 \cdot 7 \%$. The total weight loss of the gypsum rock was $7 \cdot 53 \%$ at $800^{\circ} \mathrm{C}$.

- GC decreased with increasing soaking time and confined water pressure. The GC decreased by $11 \%$ when the sample was subjected to $0.5 \mathrm{MPa}$ confined water pressure for $105 \mathrm{~d}$ of soaking.

- The compressive strength of gypsum rock decreased by 50 and $68 \%$ when the samples were subjected to $0.5 \mathrm{MPa}$ of confined water pressure for 35 and $105 \mathrm{~d}$, respectively.

- The initial modulus of elasticity of gypsum rock decreased by $70 \%$ when the samples were subjected to $0 \mathrm{MPa}$ of confined water pressure for $105 \mathrm{~d}$ of soaking. The initial modulus of elasticity of gypsum rock decreased by 43 and $50 \%$ when the samples were subjected to $0 \cdot 5 \mathrm{MPa}$ of confined water pressure for 35 and $105 \mathrm{~d}$, respectively.

- The flexural strength of gypsum rock decreased by 61 and $91 \%$ when the samples were subjected to $0.5 \mathrm{MPa}$ of confined water pressure for 35 and $105 \mathrm{~d}$, respectively.

- GC decreased with increasing soaking time and confined water pressure. The GC decreased by $11 \%$ when the samples were subjected to $0.5 \mathrm{MPa}$ confined water pressure for $105 \mathrm{~d}$ of soaking.

- Based on the RMSE and $R^{2}$, the non-linear Vipulanandan model ( $p-q$ model) predicted the stress-strain behaviour of gypsum rock at different soaking times and confined water pressures very well. The model parameters were sensitive to the GC. 
- The compressive strength and flexural strength of the normal gypsum rock decreased with increasing soaking time and confined water pressure.

\section{REFERENCES}

Agustawijaya DS (2007) The uniaxial compressive strength of soft rock. Civil Engineering Dimension 9(1): 9-14, https://doi.org/10.9744/ced.9. 1.pp. \%209-14

Ali SA (1979) Creep Properties of Evaporite Rocks with Particular Reference to Gypsum. PhD thesis, University of Sheffield, Sheffield, UK.

Aliha MRM, Ayatollahi MR and Kharazi B (2009) Numerical and experimental investigations of mixed mode fracture in granite using four-point-bend specimen. In Damage and Fracture Mechanics: Failure Analysis of Engineering Materials and Structures (Boukharouba T, Elboujdaini M and Pluvinage G (eds)). Springer, Dordrecht, the Netherlands, pp. 275-283.

Al-Layla MT and Thabet KM (1990) Formation of cavities in the alluvial deposits in Mosul City. Proceedings of the 2nd Science Conference of Mosul Dam Research Centre, Mosul, Iraq, pp. 172-185.

ASTM (2010a) D 7012-10: Standard test method for compressive strength and elastic moduli of intact rock core specimens under varying states of stress and temperatures. ASTM International, West Conshohocken, PA, USA

ASTM (2010b) D 6272-10: Standard test method for flexural properties of unreinforced and reinforced plastics and electrical insulating materials by four-point bending. ASTM International, West Conshohocken, PA, USA

Bell FG (1994) A survey of the engineering properties of some anhydrite and gypsum from the north and midlands of England. Engineering Geology 38(1-2): 1-23.

Bieniawski ZT (1967) Stability concept of brittle fracture propagation in rock. Engineering Geology 2(3): 149-162.

Biolzi L, Cattaneo S and Rosati G (2001) Flexural/tensile strength ratio in rock-like materials. Rock Mechanics and Rock Engineering 34(3): 217-233.

Biolzi L, Labuz JF and Muciaccia G (2011) A problem of scaling in fracture of damaged rock. International Journal of Rock Mechanics and Mining Sciences 48(3): 451-457.

Brady BH and Brown ET (2013) Rock Mechanics: for Underground Mining. Springer, Dordrecht, the Netherlands.

Carreira DJ and Chu KH (1985) Stress-strain relationship for plain concrete in compression. Journal of the American Concrete Institute 82(6): 797-804.

Chen YL and Azzam R (2007) Creep fracture of sandstones. Theoretical and Applied Fracture Mechanics 47(1): 57-67.

Cho N, Martin CD, Sego DC and Jeon J (2010) Dilation and spalling in axially compressed beams subjected to bending. Rock Mechanics and Rock Engineering 43(2): 123-133.

Cooper AH and Saunders JM (2002) Road and bridge construction across gypsum karst in England. Engineering Geology 65(2): 217-223.

Coviello A, Lagioia R and Nova R (2005) On the measurement of the tensile strength of soft rocks. Rock Mechanics and Rock Engineering 38(4): 251-273.

Dreybrodt W, Romanov D and Gabrovsek F (2002) Karstification below dam sites: a model of increasing leakage from reservoirs. Environmental Geology 42(5): 518-524.

Dusseault MB (2011) Geomechanical challenges in petroleum reservoir exploitation. KSCE Journal of Civil Engineering 15(4): 669-678

Efimov VP (2009) The rock strength in different tension conditions. Journal of Mining Science 45(6): 569-575.

Elizzi MAS (1976) The Time Dependent Behaviour of Some Evaporite Rocks. PhD thesis, University of Sheffield, Sheffield, UK.

Ezeldin AS and Balaguru PN (1992) Normal-and high-strength fiberreinforced concrete under compression. Journal of Materials in Civil Engineering 4(4): 415-429.
Fengxiang C and Mingjiang W (1983) Investigation of the engineering properties of a dam foundation containing gypsum seams. Rock Mechanics and Rock Engineering 16(4): 275-280, https://doi.org/10. 1007/BF01042361.

Gumusoglu MC and Ulker R (1982) The investigation of the effect of gypsum on foundation design. Bulletin of the International Association of Engineering Geology - Bulletin de l'Association Internationale de Géologie de l'Ingénieur 25(1): 99-105, https://doi. org/10.1007/BF02603199.

HaiFei Z, TiYu D, Yuan L and Qiang S (2009) Abrupt solubility of gypsum in water at high pressure and ambient temperature and its implication. Acta Petrologica Sinica 25(5): 1288-1290.

Hawkes I and Mellor M (1970) Uniaxial testing in rock mechanics laboratories. Engineering Geology 4(3): 179-285.

Heidari M, Khanlari GR, Torabi Kaveh M and Kargarian S (2012) Predicting the uniaxial compressive and tensile strengths of gypsum rock by point load testing. Rock Mechanics and Rock Engineering 45(2): 265-273.

Ingebritsen SE and Sanford WE (1999) Groundwater in Geologic Processes. Cambridge University Press, Cambridge, UK.

Jaworska J (2010) An oxygen and sulfur isotopic study of gypsum from the Wapno Salt Dome cap-rock (Poland). Geological Quarterly 54(1): $25-32$.

Johnson KS (2005) Subsidence hazards due to evaporite dissolution in the United States. Environmental Geology 48(3): 395-409.

Khalil AA and Gad GM (1972) Gypsum plasters: I. preparation of $\beta$ hemihydrates. Journal of Applied Chemistry and Biotechnology 22(6): 697-701.

Klimchouk A (1996) The dissolution and conversion of gypsum and anhydrite. International Journal of Speleology 25(3-4): 21-36, https:// doi.org/10.5038/1827-806X.25.3.2.

Koukouzas N and Vasilatos C (2008) Mineralogical and chemical properties of FGD gypsum from Florina, Greece. Journal of Chemical Technology and Biotechnology 83(1): 20-26, https://doi.org/10.1002/ jctb. 1770 .

Liang W, Zhang C, Gao H et al. (2012) Experiments on mechanical properties of salt rocks under cyclic loading. Journal of Rock Mechanics and Geotechnical Engineering 4(1): 54-61.

Lundborg N (1967) The strength-size relation of granite. International Journal of Rock Mechanics and Mining Sciences \& Geomechanics Abstracts 4(3): 269-272.

Mebarkia S and Vipulanandan C (1992) Compressive behavior of glassfiber reinforced polymer concrete. Journal of Materials in Civil Engineering 4(1): 91-105.

Mohammed A and Mahmood W (2018a) Vipulanandan failure models to predict the tensile strength, compressive modulus, fracture toughness and ultimate shear strength of calcium rocks. International Journal of Geotechnical Engineering, https://doi.org/10.1080/19386362.2018. 1468663.

Mohammed A and Mahmood W (2018b) Statistical variations and new correlation models to predict the mechanical behavior and ultimate shear strength of gypsum rock. Open Engineering 8(1): 213-226.

Mohammed AS and Vipulanandan C (2014) Compressive and tensile behavior of polymer treated sulfate contaminated CL soil. Geotechnical and Geological Engineering 32(1): 71-83.

Mohammed A and Vipulanandan C (2015) Testing and modelling the short-term behavior of lime and fly ash treated sulfate contaminated CL soil. Geotechnical and Geological Engineering 33(4): 1099-1114.

Moonen P (2009) Continuous-Discontinuous Modelling of Hygrothermal Damage Processes in Porous Media. PhD thesis, Delft University of Technology, Delft, the Netherlands.

Özkan I, Özarslan A, Geniş M and Özşen H (2009) Assessment of scale effects on uniaxial compressive strength in rock salt. Environmental \& Engineering Geoscience 15(2): 91-100. 
Geotechnical Research

Volume 6 Issue GR2
Vipulanandan $p-q$ model to predict the

effect of pressurised water on the

strengths of gypsum rock in Kurdistan

Region, Iraq

Mohammed and Salih
Rauh F, Spaun G and Thuro K (2006) Assessment of the swelling potential of anhydrite in tunnelling projects. Proceedings of the 10th IAEG Congress, Nottingham, UK, paper no. 473.

Salih NB, Collins PE and Kershaw S (2015) Dissolution influences on gypsum rock under short and long-term loading: implications for dams. In Engineering Geology for Society and Territory - Volume 6: Applied Geology for Major Engineering Projects (Lollino G, Giordan D, Thuro K et al. (eds)). Springer, Cham, Switzerland, pp. 779-783.

Shafiei A, Dusseault MB and Baghdardokht Z (2008) Geotechnical properties of soluble rocks from a dam site in Iran. Proceedings of the 42nd US Rock Mechanics Symposium (USRMS), San Francisco, CA, USA.

Singh VK and Singh DP (1993) Correlation between point load index and compressive strength for quartzite rocks. Geotechnical and Geological Engineering 11(4): 269-272.

Vásárhelyi B and Ván P (2006) Influence of water content on the strength of rock. Engineering Geology 84(1): 70-74.

Vipulanandan C and Krishnan S (1993) XRD analysis and leachability of solidified phenol-cement mixtures. Cement and Concrete Research 23(4): 792-802.

Vipulanandan C and Mohammed A (2015a) Smart cement modified with iron oxide nanoparticles to enhance the piezoresistive behavior and compressive strength for oil well applications. Smart Materials and Structures 24(12): 125020
Vipulanandan C and Mohammed A (2015b) XRD and TGA, swelling and compacted properties of polymer treated sulfate contaminated CL soil. Journal of Testing and Evaluation 44(6): 2270-2284, https://doi.org/ $10.1520 /$ jte20140280.

Vipulanandan C and Ozgurel HG (2009) Simplified relationships for particle-size distribution and permeation groutability limits for soils. Journal of Geotechnical and Geoenviromental Engineering 135(9): 1190-1197.

Vipulanandan C and Paul E (1990) Performance of epoxy and polyester polymer concrete. Materials Journal 87(3): 241-251.

Vipulanandan C and Usluogullari OF (2011) Stress-strain behavior and California bearing ratio of artificially cemented sand. Journal of Testing and Evaluation 39(4): 637-645.

Whittles DN, Kingman S, Lowndes I and Jackson K (2006) Laboratory and numerical investigation into the characteristics of rock fragmentation. Minerals Engineering 19(14): 1418-1429.

Xeidakis GS, Samaras IS, Zacharopoulos DA and Papakaliatakis GE (1996) Crack growth in a mixed-mode loading on marble beams under three point bending. International Journal of Fracture 79(2): 197-208.

Yılmaz I (2001) Gypsum/anhydrite: some engineering problems. Bulletin of Engineering Geology and the Environment 60(3): 227-230.

Yılmaz I and Sendır H (2002) Correlation of Schmidt hardness with unconfined compressive strength and Young's modulus in gypsum from Sivas (Turkey). Engineering Geology 66(3-4): 211-219.

\section{How can you contribute?}

To discuss this paper, please submit up to 500 words to the editor at journals@ice.org.uk. Your contribution will be forwarded to the author(s) for a reply and, if considered appropriate by the editorial board, it will be published as a discussion in a future issue of the journal. 